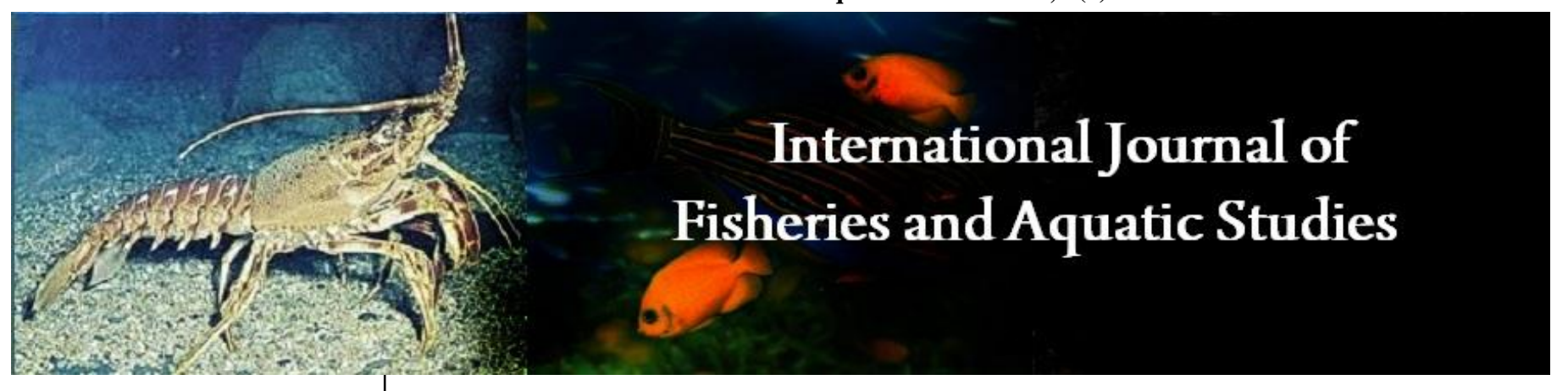

E-ISSN: 2347-5129

P-ISSN: 2394-0506

(ICV-Poland) Impact Value: 5.62

(GIF) Impact Factor: 0.549

IJFAS 2021; 9(3): 250-252

(C) 2021 IJFAS

www.fisheriesjournal.com

Received: 01-03-2021

Accepted: 03-04-2021

Shibananda Rath

Zoological Survey of India,

Freshwater Fish Section, 27 J.L.

Nehru Road, Kolkata,

West Bengal, India

Asha Kiran Tudu

Zoological Survey of India,

Freshwater Fish Section, 27 J.L.

Nehru Road, Kolkata,

West Bengal, India

Bungdon Shangningam

Zoological Survey of India,

Freshwater Fish Section, 27 J.L.

Nehru Road, Kolkata,

West Bengal, India

Corresponding Author:

Shibananda Rath

Zoological Survey of India,

Freshwater Fish Section, 27 J.L.

Nehru Road, Kolkata,

West Bengal, India

\section{First record of Osteobrama tikarpadaensis (Teleostei: Cyprinidae) from Maharashtra India}

\author{
Shibananda Rath, Asha Kiran Tudu and Bungdon Shangningam
}

DOI: https://doi.org/10.22271/fish.2021.v9.i3d.2490

\section{Abstract}

Osteobrama tikarpadensis Shangningam et al. (2020) is reported for the first time from Maharashtra, India. The species was originally described from the Mahanadi River, Tikarpada, Angul District, Odisha. It is distinguished from other members of the genus Osteobrama by having rostral and maxillary barbels; 25-26 branched anal-fin rays and 61-67 lateral line scales.

Keywords: Cyprinidae, Osteobrama, Maharashtra, new record, variations

\section{Introduction}

Members of the genus Osteobrama are frequent and abundant in lentic habitats throughout their range in Bangladesh, India, Myanmar, and Pakistan (Hora \& Misra 1940; Talwar \& Jhingran 1991; Vishwanath \& Shantakumar 2007) ${ }^{[5,10,13]}$. The genus is characteristic in having a deep and strongly compressed body, with the abdominal edge trenchant in its entirety or from the pelvic-fin base to vent; 0-2 pairs of barbels; a complete lateral line running medially; and 11-33 branched rays in the anal fin (Talwar \& Jhingran 1991) ${ }^{[10]}$.

Shangningam et al. (2020) ${ }^{[7]}$ described Osteobrama tikarpadensis from the Mahanadi River, Tikarpada, Angul District, Odisha and recognized other nine valid species within the genus viz., O. belangeri (Valenciennes 1844) ${ }^{[11]}$; O. feae Vinciguerra (1890) ${ }^{[12]}$ and $O$. cunma (Day 1888) ${ }^{[2]}$ from the Chindwin-Irrawaddy drainage of India and Myanmar; O. cotio (Hamilton 1822) ${ }^{[4]}$ from the Barak-Meghna and Ganga-Brahmaputra drainages of India and Bangladesh; O. neilli (Day 1873) ${ }^{[1]}$ from the Cauvery drainage of India; O. bakeri (Day 1873) ${ }^{[1]}$ from westflowing rivers in Kerala and O. vigorsii (Sykes 1839) ${ }^{[8]} ;$ O. dayi (Hora \& Misra, 1940) ${ }^{[5]}$ and O. peninsularis Silas (1952) ${ }^{[8]}$ from the Godavari and Krishna drainages of India.

A fish collection lot from the Erai River, Chandrapur District, Maharashtra India included two specimens of Osteobrama. Further examination of the species fully agrees with the original description of Osteobrama tikarpadensis and is reported herein for the first time from the Godavari drainage in Maharashtra, India.

\section{Materials and Methods}

Measurements were made on the left side of the specimens point to point with digital calipers to the nearest $0.1 \mathrm{~mm}$. Methods of counts, measurements and description followed Jayaram $(1999)^{[6]}$. Fin rays and number of scales were counted under a stereo-zoom Leica microscope. Measurements are given as proportions of standard length (SL) and head length (HL). The specimens are deposited in the Zoological Survey of India (ZSI), Kolkata.

\section{Results}

Osteobrama tikarpadensis Shangningam, Rath, Tudu and Kosygin, 2020

(Figure 1 and Table 1)

Material examined: ZSI FF 8791, 2, 96.2-98.9 mm SL; India, Maharashtra, Chandrapur District, Erai dam on Erai River (Godavari drainage) collected by A.K. Karmakar, 06 June 2006.

Body deep, laterally compressed. Dorsal profile sloping upward linearly to nape, then in a broad curve to dorsal fin origin, forming a distinct hump, then sloping gradually downward 
towards caudal peduncle. Ventral profile strongly curved from tip of snout to origin of anal fin. Head compressed longer than deep. Eye large situated anteriorly on head, visible from dorsal and ventral side. Mouth terminal, obliquely directed upwards. Barbels in two pairs, rostral and maxillary.

\section{Description}

Dorsal fin with iii unbranched and 8 branched rays, last unbranched ray stiff and serrated. Pectoral fin with $i$ unbranched and 16 branched rays. Pelvic fin i unbranched and 9 branched rays. Anal fin long with iii unbranched rays and 25-26 branched rays. Caudal fin deeply forked with 9+ 8 branched rays.

Scales small in size. Predorsal scale 31-33. Lateral transverse scale rows between dorsal fin origin to lateral line 12; and transverse scale rows between lateral line to pelvic fin 13 . Lateral line complete with 61-67 scales.

\section{Coloration}

In preserved specimens, dorsal and dorsolateral surfaces of head and body faint brown, lateral surface of body greyish become lighter ventrally. Dorsal, pectoral, pelvic, anal and caudal fin is pale white. An oblique black streak immediately posterior to opercle, parallel to upper opercular margin present.

\section{Discussion}

Currently, the genus Osteobrama comprised of ten valid species. The presence or absence of barbels is an important distinguishing character among the members of the genus. Based on this character, Hora and Misra (1940) ${ }^{[5]}$ assembled the species of the genus into three groups; (I) with four well defined barbels, (II) with two rudimentary maxillary barbels, (III) without barbels. After detail examination, Shangningam et al. (2020) followed Hora \& Misra (1940) [5] and categorized Osteobrama bakeri, O. feae, O. neilli and $O$. tikarpadaensis as member of (I) with four well defined barbels; $O$. dayi and $O$. vigorsii as member of (II) with two rudimentary maxillary barbels and $O$. belangeri, $O$. cotio, $O$. cunma and $O$. peninsularis as a member of group (III) without barbels.

Osteobrama tikarpadaensis is superficially similar to $O$. bakeri, $O$. feae and $O$. neilli in having two pairs of barbels. However, it is distinguished from all three in having minute (vs. well defined) barbels. Furthermore, it is distinguished from $O$. bakeri in having more branched anal-fin rays (25-26 vs. 11), more pre-dorsal scales (31-32 vs. 15), more lateralline scales (61-67 vs. 44) and more scales between lateral line and pelvic fin base (13 vs. 51/2); from $O$. feae in having fewer pre-dorsal scales (31-32 vs. 34-39), lesser body depth (33.1$34.6 \%$ SL vs. 42.3-54.8), greater head length (25.4-25.7\% SL vs. 20.9-21.5), and more branched pectoral-fin rays (16 vs. 14); and from $O$. neilli in having more lateral-line scales (66-67 vs. 52-57), more branched anal-fin rays (25-26 vs. 16-18), more pre-dorsal scales (31-32 vs. 19-22), lesser predorsal distance (53.7-54.0 \% SL vs. 53.0-56.5), a smaller eye diameter (vs. 6.1-6.9\% SL vs. 8.7-11.6) and a greater interorbital distance (7.6-8.0 \% SL vs. 5.9-7.3).

The present study fully agrees with the description of Osteobrama tikarpadaensis Shangningam et al. (2020) [7]. However, there are slight variations in the body morphometry, which is presented in Table 1. The minor difference in the fin length of dorsal, pelvic and caudal probably indicates that as the species grows to its adult size, its fin lengths reduce or remains constant. There are two divergent characters between viz., pre-dorsal distance and caudal peduncle length. The specimens under study are smaller sized as compared to the type species. The probable reasons of minor differences could be due to its distributional range and genetic variation.

It is evident from the present study that the range of distribution of Osteobrama tikarpadaensis extends from the Mahanadi River in Odisha to the Godavari drainages of Maharashtra, India.

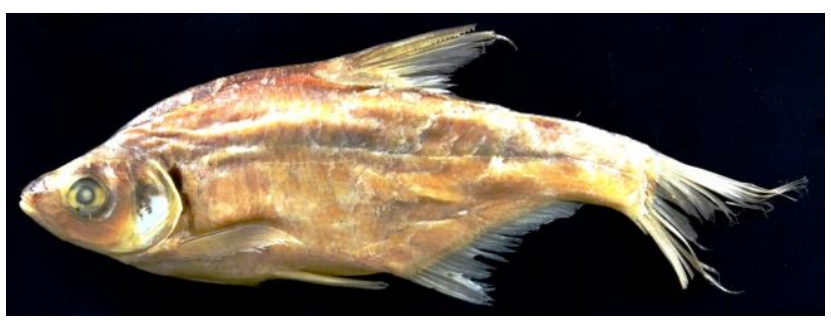

Fig 1: Osteobrama tikarpadensis ZSI FF 8791, 98.9 mm SL.

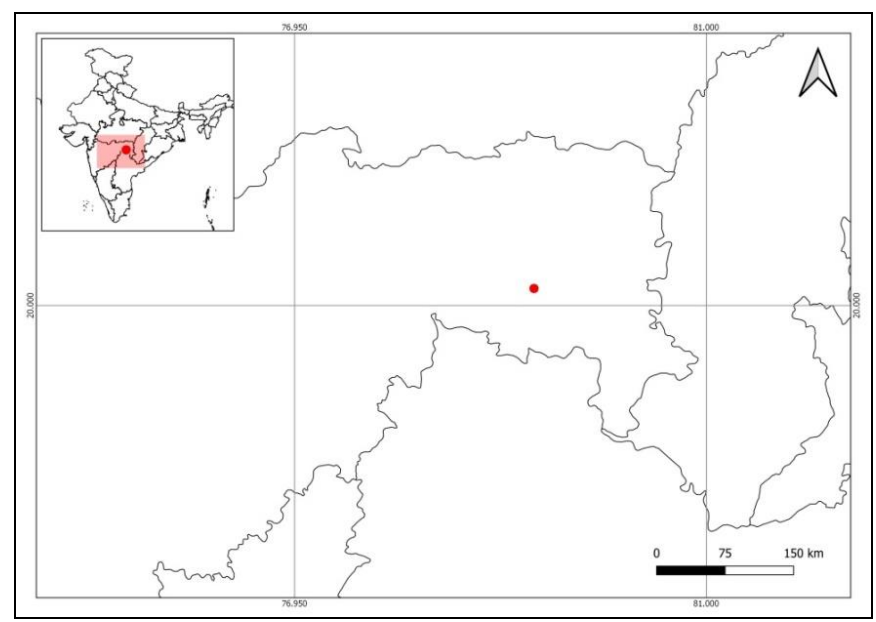

Fig 2: Map showing collection site of Osteobrama tikarpadensis.

Table 1. Morphometric measurements of Osteobrama tikarpadaensis Shangningam et al. 2020.

\begin{tabular}{|c|c|c|}
\hline Character & ZSI FF 8791 & ZSI FF 7494-7475 \\
\hline Standard length (mm) & $96.2-98.9$ & $90.3-129$ \\
\hline \% SL & & \\
\hline Body depth & $33.1-34.6$ & $34.5-39.5$ \\
\hline Head length & $25.4-25.7$ & $24.5-28.8$ \\
\hline Head width & $11.7-12.0$ & $8.7-10.0$ \\
\hline Caudal peduncle length & $10.2-10.5$ & $14.5-15.6$ \\
\hline Dorsal-fin base length & $11.8-12.6$ & $13.0-14.2$ \\
\hline Dorsal fin length & $30.7-33.7$ & $24.6-29.4$ \\
\hline Pelvic fin length & $19.9-21.6$ & $17.6-18.9$ \\
\hline Predorsal length & $53.7-54.0$ & $37.8-40.4$ \\
\hline
\end{tabular}

\section{Acknowledgements}

We are grateful to Kosygin Laishram, Zoological Survey of India for permission to undertake the present work.

\section{References}

1. Day F. On new or imperfectly known fishes of India. Proceedings of the Zoological Society of London, 1873 (Pt 1), Art. 4 (for 4 )1873-236-240.

2. Day F. Fishes of India. Supplement. October 1888. William Dawson, London 1888;38:779-816.

3. Day F. The Fauna of British India, including Ceylon and Burma. Fishes. Taylor and Francis, London 1889;2:509.

4. Hamilton F. An account of the fishes found in the river 
Ganges and its branches. Edinburgh \& London, 1822; vii+ 405, 39 pls.

5. Hora SL, Misra KS. Notes on fishes in the Indian museum. XL. On fishes of the genus Rohtee Sykes. Records of the Indian Museum 1940;42(1):155-172.

6. Jayaram KC. The freshwater fishes of Indian region. Narendra Publ. House, New Delhi, 1999, 551.

7. Shangningam B, Rath S, Tudu AK, Kosygin L. A new species of Osteobrama (Teleostei: Cyprinidae) from the Mahanadi River, India with a note on the validity of $O$. dayi. Zootaxa 2020;4722(1):68-76.

8. Silas EG. Further studies regarding Hora's Satpura Hypothesis. 2. Taxonomic assessment and levels of evolutionary divergence of fishes with the so-called Malayan affinities in Peninsular India. Proceedings of the National Institute of Sciences of India 1952;18:423-448.

9. Sykes WH. On the fishes of the Deccan. Proceedings of the General Meetings for Scientific Business of the Zoological Society of London, 1838 1839(6):157-165.

10. Talwar PK, Jhingran AG. Inland fishes of India and adjacent countries. Oxford \& IBH publishing Co. New Delhi, Bombay and Calcutta 1991;1:541.

11. Valenciennes A. Histoire naturelle des poissons. Tome dix-septième: Suite du livre dix-huitième. Cyprinoïdes, 1844; 17:487-519.

12. Vinciguerra D. Viaggio di Leonardo Fea in Birmania e regioni vicine. XXIV. Pesci. Annali del Museo Civico di Storia Naturale di Genova, Serie 1890;2(9):129-362, pls. 7-11.

13. Vishwanath W, Shantakumar M. Fishes of the genus Osteobrama Heckel of northeastern India (Teleostei: Cyprinidae). Zoo's Print Journal 2007;22(11):2881-2884. 